\title{
HARDY (René), Contrôle social et mutation de la culture religieuse au Québec, 1830-1930
}

Montréal, Boréal, 1999, 284 p. (bibliogr.)

\section{Raymond Courcy}

\section{OpenEdition}

\section{Journals}

Édition électronique

URL : http://journals.openedition.org/assr/20565

DOI : $10.4000 /$ assr.20565

ISSN : $1777-5825$

\section{Éditeur}

Éditions de l'EHESS

Édition imprimée

Date de publication : 1 juillet 2000

Pagination : 82-83

ISBN : 2-222-96691-4

ISSN : 0335-5985

\section{Référence électronique}

Raymond Courcy, «HARDY (René), Contrôle social et mutation de la culture religieuse au Québec,

1830-1930 », Archives de sciences sociales des religions [En ligne], 110 | avril-juin 2000, document

110-27, mis en ligne le 19 août 2009, consulté le 21 septembre 2020. URL : http://

journals.openedition.org/assr/20565; DOI : https://doi.org/10.4000/assr.20565

Ce document a été généré automatiquement le 21 septembre 2020.

(c) Archives de sciences sociales des religions 


\title{
HARDY (René), Contrôle social et mutation de la culture religieuse au Québec, 1830-1930
}

\author{
Montréal, Boréal, 1999, 284 p. (bibliogr.)
}

\section{Raymond Courcy}

\section{RÉFÉRENCE}

HARDY (René), Contrôle social et mutation de la culture religieuse au Québec, 1830-1930, Montréal, Boréal, 1999, 284 p. (bibliogr.)

1 L'historiographie religieuse du Canada français proposée par des idéologues catholiques est maintenant dépassée. Elle décrivait un Québec qui aurait été de tout temps profondément chrétien grâce à la présence d'une institution ecclésiale extrêmement prégnante. Or, jusqu'au début du XIX siècle, le peuple était peu enclin aux dévotions et le clergé peu nombreux. Demeure alors la question qui fascine tous les historiens. Comment se fait-il que, un siècle plus tard, en 1900, la pratique soit devenue quasi unanime et l'institution religieuse aussi puissante dans tous les secteurs de la société ? Ce livre est au cœur d'un débat. Certes, tout le monde admet que cette reprise en main de l'Église se situe dans les années quarante après les événements de 1837-1838 qui sont l'échec de la « révolte des patriotes » et d'une petite bourgeoisie anticléricale. Mais les interprétations divergent lorsqu'il s'agit de donner les raisons de cette reprise en main.

2 Certains, statistiques à l'appui, parlent de "réveil religieux » à la suite de retraites prêchées au clergé et dans les paroisses. Le changement culturel reposerait sur les dispositions renouvelées des individus, la structuration de l'appareil ecclésial et le charisme des leaders. Notre auteur préfère parler de renouveau religieux et cherche à montrer «comment les rapports sociaux, analysés dans les conjonctures où ils évoluent, ont contribué à la diffusion du modèle de comportement suggéré par le 
clergé » (p. 119). Étant entendu que, « au début du XIX', le catholicisme est devenu l'un des traits identitaires des Canadiens français ", (p. 214) c'est une nouvelle culture qui se met progressivement en place. L'effondrement des élites après 1837-1838 rehausse le prestige du clergé, le gouvernement colonial cautionne l'influence de l'institution religieuse qui garantit la paix sociale. « Pour la première fois depuis la défaite de 1760, l'Église a les coudées franches et peut se développer. Guidée par le dynamisme de l'épiscopat montréalais, elle entreprend un vigoureux programme de réforme des structures administratives, recrute des prêtres français, adopte l'ecclésiologie et la spiritualité ultramontaines et révise en profondeur le programme de formation des prêtres. Forte de cette cohésion nouvelle, l'Église entreprend la conquête de la société civile.» (p. 155) Pour cela elle prend progressivement le contrôle du système scolaire, déploie de nombreuses réalisations sociales et sanitaires, œuvre dans le journalisme et met en place de multiples associations. Et R.H. affirme : «il m'apparait que l'explication de la montée graduelle de pratiques religieuses unanimes doit être recherchée de ce côté» (p. 155).

Dans le développement de son argumentation, il prend le parti de la monographie, sans négliger éventuellement les statistiques. Ce qui lui permet d'expliciter le prosélytisme protestant (chap. 1), fragile et divisé, qui suscite en réaction un encadrement paroissial des fidèles de la part de l'Église. Il montre aussi comment les retraites prêchées dans les années quarante dans la paroisse Notre Dame de Québec (chap. 2) ont eu certes un succès certain, mais n'ont pas entraîné une conversion radicale de l'ensemble de la population. De même la lente progression de la pratique pascale et religieuse dans les diocèses de Trois Rivières et Montréal (chap.3) avec la dimension ligorienne de la confession, est expliquée par l'efficacité de l'encadrement religieux et la force d'un conformisme social de plus en plus prégnant. Les observations faites à propos de la «judiciarisation» des conflits entre clercs et fidèles (chap.4) et des jurons comme moyen de résistance symbolique à la puissance ecclésiale (chap.5) ne font que confirmer cette thèse de la construction progressive et efficace d'une culture religieuse ayant prise sur l'ensemble de la société.

4 Au terme de cette démonstration, une question reste cependant posée. Cette conquête de la société repose en particulier sur un encadrement clérical efficace. Comment cela a-t-il pu se réaliser dans la période qui a immédiatement suivi la «révolte des patriotes» alors même que le clergé était en quantité limitée ? Comment expliquer alors cet attrait soudain pour la carrière ecclésiastique qui a fait doubler le nombre des prêtres entre 1840 et $18607 \mathrm{Au}$-delà de l'intérêt de la lecture de ce livre, notons également celui d'une bibliographie judicieuse proposée à la fin de l'ouvrage qui ne peut que combler tous les chercheurs qui s'intéressent à l'histoire religieuse du Québec. 